\title{
Learner Autonomy Practices in English Language Teaching in EFL Context
}

Jagadish Paudel

\begin{abstract}
Einstein says "I never teach my students. I simply provide the situations in which they can learn". In line with this saying the learner autonomy (LA) approach provides learners with situations where they can learn independently in their own pace. This learner centered approach to teaching, emerged during the 1980s, aims at empowering learners by transforming responsibilities to them. This study aimed at exploring the practice level scenario of LA in English language teaching and learning. To this end, I employed the qualitative research design i.e. I observed teachers' classes and conducted Focus Group Discussion (FGD) withthe students. The information elicited from participants was transcribed, codified, categorized and finally themes were generated. The study revealed that, though the teachers and the students were affirmative towards $L A$, in a real sense, the majority of them did not adopt in English language teaching and learning. The classroom ritual is still teacher oriented. On the one hand, the teachers are still in the cockpit of pedagogy without providing any agency for the students. On the other hand, students' readiness for bearing responsibility of their learning was found weak. They preferred attachment to teachers without taking charge of learning.
\end{abstract}

Keywords: learner autonomy, practices, resources

\section{Introduction}

There has been a noticeable paradigm shift in language pedagogy; the shift from teacher centered pedagogy to learner centered approach- LA. These days, professional teachers appreciate self-reliant learners and promote LA as a main goal, where learners are self-directed taking responsibilities for their own learning (Harmer, 2007). The recent trend values learners' experiences, interests, feelings and learning style, and is directed to make students independent in their learning.LA approach to language teaching was first introduced by Holec through his work Autonomy and foreign language learning, published by the Council of Europe in 1979 (Holec,1981). Thanasoulas (2000) has listed some synonymous words with LA including 'independence' (Sheerin, 1991), 'language awareness' (Lier, 1996; James \& Garrett, 1991), 'self-direction' (Candy, 1991), 'andragogy' (Knowles, 1980, p.183). The ideas that cluster around the concept of LA have also been promoted under other banners- for example, 'humanistic language teaching', 'collaborative learning', 'experiential learning', 'the learning- centred classrooms (David cited in Byram, ed. 2010, p.70).

LA is commonly defined as "the ability to take charge of one's learning" (Holec, 1981, p. 3). In fact, it is the approach which leads learners to be responsible and makes them accountable for theirown learning. It is the shift of accountability and power from teachers to learners by changing the traditional roles of the both (Banerjee, 2011). Supporting Banerjee's view, Hedge (2000, p. 410) writes "learner autonomy is the ability of the learner to take responsibility for his or her own learning and to plan, organize, and monitor the learning process independently of the teacher". Indeed, under the LA approach, learners are required to 
plan, organize, and monitor their own learning autonomously and independently. LA regards teaching as a redeployment of power between teachers and students; and learning is taken as an individualistic approach rather than social process. In this connection, Thanasoulas writes (2000) "autonomy is a departure from education as a social process, as well as in terms of redistribution of power attending the construction of knowledge and the roles of the participants in the learning process" (p.223). LA gives power and freedom to learners;allows them to construct knowledge; make learners independent and critical in their learning. Little (1991) asserts thatLA is "essentially a matter of the learner's psychological relation to the process and content of learning - a capacity for detachment, critical reflection, decision-making, and independent action" (p.4).

Apparently, LA is an approach which invokes the learners to take responsibilities leading them to decide learning goals, choose learning processes and methods, and identify their own learning needs. For Pennycook (1997), LA is “the struggle to become the author of one's own world, to be able to create own meaning, to pursue cultural alternatives amid the cultural politics of everyday life" (p.39). In the similar vein, Young (1986) avers, "the fundamental idea in autonomy is that of authoring one's own world without being subject to the others" (p.19). Obviously, both the authors have argued for freedom of learners in adopting preferential styles, strategies, and activities in their learning. LA is a kind of autonomous learning where learners get chance to learn in individualized, self-chosen styles without much depending on teacher. Regarding autonomous learning, Macdougall (2008) writes "it is a type of learning which is characterized by personalization, self-directedness and less dependency on the educator for affirmation, and which therefore enhances rather than hinders the capacity for constructive collaborative participation in the workplace" (p.224).From the above definitions and citations, it can be inferred that LA is associated with learners' freedom, and it is directed to make learners autonomous in their study. It allows the learners to learn in preferential options in their own learning styles and strategies. Similarly, it drives the learners to be independent in their learning by transferring responsibilities, giving ideas and showing ways to learn independently.

\section{The context}

The whole world is rapidly shifting from authoritative regime to democracy. This effect has been pervasive in educational field, too. As we glance at the western academia, they are embracing the LA approach to teaching and learning with the aim of empowering their learners. In the recent years, the LA approach to ELT has been hotly discussedin Nepalese academia too. However, it has not been put into practice in most of schools and colleges yet. Describing the scenario, Pokhrel (2013) writes:

English teachers are less motivated to engage students in activities. Due to the practice of teacher centered-teaching method, students wait for teachers to solve problem and they become reluctant to expose them with others using English language even in ELT classroom. It shows that there is lack of integrity in students' schooling, teachers' teaching, demands of society and perspectives of contents in ELT. (p.130)

Indeed, most students are not ready to take charge of their learning; teachers are obliged to take 
charge of their learning. The greatest challenge lies ahead to develop a sense of responsibility among the students so thatthey strive to be independent in learning. In this regard, Bashyal (2012) writes "one of the greatest challenges to the teachers is to develop a sense of responsibility among their learners so that the learners will understand why and how they learn and be willing to take an active role in their learning" (p. 60). Likewise, it has been found that most of the teachers do not want to change their traditional roles. It has been observed that teachers are depositing knowledge to students rather than promoting them to be autonomous. However, both the teacher and students were found positive in adopting the LA approach in ELT (Joshi, 2011). Though few studies have been executed on LA, however, if we go through research papers that deal with LA, we find very limited researches that were carried out to explore the practices of LA in the Nepalese context. Hence,this study was carried out to explore the practices of LA in ELT classroom and in students' learning.

\section{Methodology}

For this, I adopted the qualitative design in order to explorethe teachers'practices of LA in the classroom. Further, I employed the participant observation research tool to dig out the in-depth information. I observed six teachers' classes and performance. I codified observed classes as $\mathrm{CO} 1, \mathrm{CO} 2, \mathrm{CO} 3, \mathrm{CO} 4$, CO5 and CO6. FGD with the 78 students was conducted. While preparing research tools, utmost attention was paid to the roles of teachers in classroom teaching and students activities as advocated by LA. Both the teachers and the students were selected purposively from Doti and Dadeldhura Districts. In order to record the data, a checklist was prepared and also note was taken during FGD.

\section{Results and Discussion}

Based on the data obtained from the class observations and FGD, themes are developed and interpreted.

\section{Teacher Controlled Classroom Atmosphere}

Learners are argued to take the responsibility of their learning themselves to enhance learner autonomy (Harmer, 2007; Little, 1999). However, teachers' classroom observation revealed that all the teachers did not transfer the responsibility to their learners; rather they themselves tookcharge while instructing to them. The shift of accountability and power from teacher to learner by changing the traditional roles of both (Banerjee, 2011; Hedge, 2000) has not been practiced. They did not assign task such as pair work, group work, and project work. Teachers did not deploy their power to learners. Out of 6 teachers, only one teacher taught in generating mode and all others taught in depositing mode (Freire, 1972). Similarly, none of the teacher asked the learners to correct their mistakes and errors themselves. Although LA gives power and freedom to learners and allows them to construct knowledge (Thanasoulas, 2000), Teachers took teaching learning activities as self-agency, instead of deployment of power and responsibilities to learners. Besides, they did not create situation to put their opinions on the teaching topic. 


\section{Vignette I (CO2)}

The teacher began his class by introducing teaching topic. He did not ask the students to put opinions on the teaching topic. He assigned class work to the students. He allocated half of the class time for making students practicing the language items. He used problem solving technique in the classroom. But it was found that he did not provide options in carrying out class work; he did not ask the students to work in group work and pair; he did not ask the students to assess their work themselves. He gave equal opportunity to all students. He maximized students-talking-time (STT) rather than TTT.

Four teachers out of six maximized TTT; they did not give chance to students to put their views and ideas on the topic being taught. The teachers played authoritative role rather than democratic role: a facilitator of learning, an organizer of learning opportunities, a resource person providing learners with feedback and encouragement, and creator of learning atmosphere and learning space (Kohonean et al., 2001, p. 40). They did not employ democratic practice in the classroom. They did not offer favored options in learning rather they impose without considering students interests and feelings. In LA practice, learners are required to set their own goals and choose their own learning activities (Little, 1995). They did not provide chance to choose homework, class work, project work and learning techniques. Likewise, they did not encourage the students to use reference materials, supplementary. In the same way, none of the teachers encouraged the learners to prepare learning notes themselves. Overall, teachers did not play their as advocated by LA.

\section{Attachment to Teacher and Lack of Self-directedness}

The study explored that the learners did not take the charge of their own learning and they did not have their own plan for learning. As Little (1999) advocates LA as the learner's psychological relation to the process and content of learning- a capacity for detachment, critical reflection and decision making, the learners were not found to have capacity for detachment and independent action; rather they want to be deposited from their teachers delivery; out of 78 students, only 11 of them had the habit of designing questions and answering the questions themselves, especially at the time of examination. The learners in LA are expected to be oriented towards self-directed learning, self-instruction and self-accessed learning (Gardener, 1999; Macdougall, 2008). It was found that, only very few learners had the habit of reading several times when they do not understand reading text. Similarly, only 9 students preferred to prepare learning notes based on their teacher's delivery. Likewise, they expressed that they do not read extra-books and materials (poems, stories, essays, novels and other materials) for improving their English.

\section{Vignette II (CO6)}

The teacher started the class by introducing teaching topic "Othello"- poem. He delivered lecture very nicely relating the topic contextually throughout class period. But it was found that he did not generate any ideas and opinions on the topic being taught from the students; he did not conduct group work; he did not involve the students in guessing work; he did not ask the students to assess work themselves; he did not suggest the students to consult supplementary and reference materials; 
he did not assign homework. Similarly, it was found that the teacher did not encourage the students to prepare learning notes themselves. At last, the teacher asked the students an oral question from topic he had taught on the period, the students responded in Nepali.

Viewing at the CO6 from the LA point of view, it was found that the class was not satisfactory in terms of assigning class work, group work, providing chances forthe students to put their views, asking them to guess learning content, involving them to assess their own work, encouraging them to prepare learning notes themselves, and asking them to consult additional materials at their home. None of the students had allocated fixed time for self-study at home. They reportedthat they do not like to take risk while learning in the classroom. They do not dare to put their opinions when they are not sure of the answers.

\section{Dearth of Resources}

Both the teachers and students are expected to go beyond the classroom to bring learner autonomy into action. That is, they can use technologicaltools such as TV, Radio, and also surf online materials which help them to learn outside the classroom. In this connection, Rana (2013) writes, "Technology has turned into one essential aspect of society that helps students to understand the bigger picture of the world and not just stay confined to what schools and teachers teach them within their classrooms" (p.12). Technology has made greater access of materials; due to it, online resources are available to almost everyone; picking a language of choice has become possible (Chik, 2018). The learners and the teachers need not be dependent on university and schools library; rather they can use online learning materials at their own home and schools. From the study, it was found that none of the schools had managed newspapers for the students and had installed Wi-Fi in their schools. Digital practices and learning beyond the classroom (Benson \& Nunan, 2004; Murray, 2008; Richards, 2014) are rare in pedagogy. Only 48 students had the Ajanta dictionary at home. Similarly, the schools did not have resources materials for improving English. Only very few language learners converted their out of class digital practices into learning events such as using digital games, photo and media sharing (Chik, 2018).Likewise, the students did not have extra reading materials at home. They showed dependency on teachers' notes rather than own notes prepared consulting the online resources. The learners, in this study,werefound to have the deep rooted notion that they are knowledge receivers rather than the creators. Therefore, they prefer readymade resources available in their yard. They are reluctant in searching the resources from google and other e- networks.

\section{Vignette III from FGD}

We do not watch English news on TV channels and listen English news in radio for developing our English language skills. We do not have laptop and computer at home for listening and watching English film and recorded speech. All of us use the Internet for Facebook purpose using cell phone but none of us use the Internet for consulting and searching course related learning materials and other English improving materials; we have never visited Google site for study purpose. While chatting with friends, we use Roman (Nepali) language instead of using English language. Similarly, we do not have the access of English newspapers and Wi Fi, ADCL Internet facility at our school to 
improve our English ourselves. We use only guide (bazaar-note: non-authentic and non-prescribed notes) as reference materials. We do not have smart phone for installing dictionary on mobile phone. Similarly, we do not have Ajanta Dictionary (English to Nepali dictionary) at home. Even if we have, majority of us do not have the habit of looking meaning ourselves using dictionary. We would like to get learning notes from teacher since that does not demand extra-labour and we also believe that learning notes prepared by teacher is more accurate and secure; rather than the learning notes prepared by ourselves.

Just like the teachers, the students did not embrace the LA approach in their learning. Viewing the FGD from the LA perspective, it was foundthat they do not strive to be autonomous as they do not have the habit of watching English movies and programs on TV, listening to English news and songs on the radio, reading materials beyond the syllabi and so on. Similarly, it was showed that the majority of the students do not like to prepare notes themselves; they do not strive to read difficult texts and understand themselves. Areported, none of them had the habit of watching English news on TV channels and listen to English news on the radio for promoting their language skills. The study revealed that only 22 students used the internet via cell phone only for the Facebook purpose but none of them were found using the internet for improving English.From the study, it is inferred that the students are unware of the potential benefits of technology and resources for learning language themselves.

\section{Conclusion and Implications}

The African saying goes "A good father does not give his son meat. Instead, he gives him a bow and arrow, and teaches him to hunt". In the same way, the LA approach to ELT does not make the students dependent on the teacher; rather it encourages them to be self-reliant learners. In LA, students are involved in decision-making as well as they are encouraged to take charge of their own learning by assigning tasks as per their interests and preferences. It allows students to develop their potential by letting them learn at their own pace and style with privileged options. Similarly, students can learn English language themselves using technology. There are abundant online materials for learning English which can be used for directing learners to learn independently. Despite having vital implication of LA, the study revealed that the classroom atmosphere was controlled by teachers rather than leading the students to be autonomous by asking them to work themselves. Similarly, teacher addiction and lack of self-directedness werefound among the students. Likewise, the students did not make use of technological tools for learning English since they are unaware of the possible usages of the tools for learning English autonomously.

From the study, it can be inferred that, for leading students to be autonomous, teachers should transfer responsibility to students. Students should be provided opportunities to put their views and ideas on the topic being taught. The teachers should play democratic role: a facilitator of learning, an organizer of learning opportunities, a resource person providing learners with feedback and encouragement, and creator of learning atmosphere and learning space (Kohonean et al., 2001, p. 40). They should offer favored options in learning rather imposing without considering students interests and feelings. Similarly, students should be given opportunities to choose homework, class work, project work and learning techniques. 
Likewise, teachers should encourage students to use reference materials, supplementary. In the same way, students should be encouraged to prepare learning notes themselves. The learners in the LA are expected to be oriented towards self-directed learning, self-instruction and self-accessed learning (Gardener, 1999; Macdougall, 2008). Likewise, they should read extra-books and materials (poems, stories, essays, novels and other materials) for improving their English. Learner autonomy, to bring it into action, both the teachers and students are expected to go beyond classroom. That is, they can use technological tools such as TV-for listening and watching English news and films, Radio-for listening English news and music, and also surf online materials which help them to learn outside classroom. The learners and teachers need not depend on schools and university library; they can use technological tools and make digital practices for learning beyond the classroom (Benson \& Nunan, 2004; Murray, 2008; Richards, 2014).

\section{References}

Banerjee, S. (2011). Learner autonomy in multicultural EFL classrooms: Probabilities and prospects. NELTA conference proceedings, 25-27.

Balçıkanl1, C. (2010). Learner Autonomy in Language Learning: Student Teachers' Beliefs. Australian Journal of Teacher Education,35(1).http://dx.doi.org/10.14221/ajte.2010v35n1.8

Benson, P. (2007). Autonomy in language teaching and learning. State-of-the article. Language teaching, 40 (1), 21-40.

Benson, P., \& Nunan, D. (Eds.). (2004). Learners' stories: Difference and diversity in language learning. Cambridge, UK: Cambridge University Press.

Benson, P., \& Reinders, H. (Eds.). (2011). Language learning and teaching beyond the classroom: Theoretical and practical perspectives. Basingstoke, UK: Palgrave Macmillan.

Brown, H. D. (1994). Principles of language learning and teaching. Landon: Prince Hall.

Byram, M. (Ed.) (2002). Routledge encyclopedia of language teaching and learning. London and New York: Routledge.

Camilleri, G.(1990). Learner autonomy: The teachers'views. Germany: Council of Europe.

Chik, A. (2018). Learner autonomy and digital practices. In Chik, Aoki and Smith (eds.). Autonomy in language learning and teaching. UK: Springer Nature

Davies, P. \& Pearse, E. (2008). Success in English teaching. New York: Oxford University Press.

Gardener, D. \& Miller, L. (1990). Establishing self-access: From theory to practice. Cambridge: Cambridge University Press.

Hedge, T. (2008). Teaching and learning in the language classroom. Oxford: Oxford University Press.

Harmer, J. (2007). The practice of English language teaching. London: Longman.

Holec, H. (1981). Autonomy and foreign language learning. Oxford: Pergamon.

Joshi, K. R. (2011). Learner perceptions and teacher beliefs about learner autonomy in language learning. Journal of NELTA, vol. 16, 13-29.

Kehrwald, J. (2005). Learner autonomy in the LOTE classroom: A case study of teacher and student beliefs about roles and responsibilities. An unpublished M. A. thesis, University of Queensland- Australia.

Kohonen, V. 1992. Experiential language learning: second language learning as and Teaching, 14-39.

Kumar, R. (2006). Research Methodology (2nd ed.). Australia: Pearson Education. 
Kumaravadivelu, B. (2001). Toward a post method pedagogy. TESOL Quarterly, 35/4, 537-560.

Lacey, F. (2007). Autonomy, never, never, never! Independence, 42, 4-8.

Lamb, T. \& Reinders, H. (2008). Learner and teacher autonomy: Concepts, realities, and responses. Netherlands: John Benjamin Publishing.

Little, D. (1991). Learner autonomy: Definitions, issues and problems. Dublin: Authentik.

Little, D. (1995). Learning as dialogue: The dependence of learner autonomy on teacher autonomy. System 23.2, $175-182$

Littlewood, W. (1997). Self-access: Why do we want it and what can it do? In Benson \& Voller (Eds.), 79-92. Macdougall, M. (2008). Ten tips for promoting autonomous learning and effective engagement in the teaching of statistics to undergraduate medical students involved in short-term research project. Journal of Applied Quantitative Methods 3, 223-240.

Murray, G. (2008). Pop culture and language learning: Learners' stories informing EFL. Innovation in Language Learning and Teaching, 2, 1-16.

Neupane, M. (2010). Learner autonomy: Concept and considerations. Journal of NELTA, 15,114-120.

Paudel, J. (2015). The attitudes towards learner autonomy and its current practices in ESL/EFL classroom at higher secondary level (10+2): A case of Dadeldhura and Doti districts. An unpublished mini-research report, University Grants Commission, Sanothimi, Bhaktpur, Nepal.

Paudel, J. (2013). Learner autonomy and some strategies of fostering learner autonomy in ESL or EFL classes. Saugat, 4, Tikapur Multiple Campus, Kailali.

Pokhrel, S. (2016). Learner Autonomy: A western hegemony in English language teaching to enhance students' learning for non-western cultural context. Journal of NELTA, 21, 128-139.

Richards, J. C., \& Schmidt, R. (2010). Longman dictionary of language teaching and applied linguistics (4th ed.). London: Longman (Pearson Education).

Richards, J. C. (2014). The changing face of language learning: Learning beyond the classroom. RELC, 46, $5-22$.

Thanasoulas, D. (2000). What is Learner Autonomy and How Can It Be Fostered? The Internet TESL Journal, VI, (11). Retrieved from http://iteslj.org/Articles/Thanasoulas-Autonomy.html

\section{Class Observation Checklist}

Name of the teacher:

Grade:

\section{Appendix A}

\begin{tabular}{|c|c|c|c|c|}
\hline S. $\mathbf{N}$. & Questionnaires & Yes & No & Remarks \\
\hline 1. & Did the teacher motivate the students before starting the lesson? & & & \\
\hline 2. & Did the teacher give chances to reflect their learning experiences (put opinions) to the students? & & & \\
\hline 3. & Did the teacher assign class work during the class time? & & & \\
\hline 4. & Did the teacher provide options/choices to the students while assigning works? & & & \\
\hline 5. & Did the teacher use problem-solving technique in the classroom? & & & \\
\hline 6. & Did the teacher assign group and pair work? & & & \\
\hline 7. & Did the teacher ask the students to prepare learning notes themselves? & & & \\
\hline 8. & Did the teacher maximize STT? & & & \\
\hline 9. & Did the teacher ask the students to assess their work themselves? & & & \\
\hline
\end{tabular}




\begin{tabular}{|l|l|l|l|}
\hline 10. & Did the teacher give feedback? & & \\
\hline 11. & Did the teacher assign homework? & & \\
\hline 12. & Did the teacher suggest the students to use reference and supplementary materials at their home? & & \\
\hline 13. & Were the students participating actively in classroom? & & \\
\hline 14. & Did the students involve in guessing work? & & \\
\hline
\end{tabular}

\section{Appendix B}

\section{FGD with the Students}

\begin{tabular}{|c|c|}
\hline S. N & FGD Questionnaires to the students \\
\hline 1. & Does your teacher give you reward when you do good work? \\
\hline 2. & Does your teacher ask you to correct your mistakes yourselves? \\
\hline 4. & Do you read several times yourself when you do not understand something? \\
\hline 5. & Do you prepare learning notes/summaries yourself on basis of teacher's delivery? \\
\hline 6. & Why do you prefer learning notes prepared by teachers; rather than preparing yourselves? \\
\hline 7. & Do you like self and peer correction or teacher's correction? \\
\hline 8. & Do you read poems, stories, essays, novel at your free time? \\
\hline 9. & Have you ever design questions yourself and answer them sometimes? \\
\hline 10. & Do you prefer learning by discussing and sharing with your friends? \\
\hline 11. & $\begin{array}{l}\text { Do you listen and watch English news, and other programmes in different radios channels and TV channels with the aim } \\
\text { of improving English? }\end{array}$ \\
\hline 12. & Do you watch Hollywood movies with the aim of improving English? \\
\hline 13. & Do you have laptop or desktop computer with you? \\
\hline 14. & Do you have Internet access at your home? \\
\hline 15. & Do you use Internet for your study purpose? \\
\hline 16. & Do you use facebook? \\
\hline 17. & Do you use facebook for study purpose? \\
\hline 18. & Which language do you use while chatting into chat box? \\
\hline 19. & Do you read extra materials -newspaper, magazines, reference books etc.? \\
\hline 20. & Do you have Oxford Advance Learner Dictionary at your home? \\
\hline 21. & Do you use dictionary? \\
\hline 22. & Is there Internet access at your school? \\
\hline 23. & How much time do you spend for learning English at your home? \\
\hline
\end{tabular}

Mr. Jagadish Paudel, a faculty of Central Department of Education, TU, has earned M.Ed and MA in English from TU in 2006 and 2009 respectively. He has been associated with the field of ELT for eleven years. To his credit, he has published a couple of academic journal articles in ELT and presented papers at national and international ELT conferences. 